\title{
EFL Undergraduate Students' Perceptions of Online Learning Applications during the COVID-19 Outbreak
}

\author{
Nurmala Hendrawaty ${ }^{1 *}$, Tri Angkarini², Ayu Bandu Retnomurti ${ }^{3}$ iD \\ 1,2,3 English Education Program, Universitas Indraprasta PGRI, Jakarta, Indonesia \\ *Corresponding author: malarumapea@gmail.com
}

\begin{abstract}
Covid-19 has affected the educational system worldwide, and it makes the teaching and learning process done through online learning. This study aims to investigate EFL undergraduate students' perceptions of utilising online learning applications during the Covid-19. There were 200 participants chosen with simple random sampling. The research instrument was an online questionnaire using a Likert scale of four items. Then data analysis employed a qualitative descriptive method to analyse two indicators: experience and comfort. The findings showed that these indicators were in the same category (positive). It indicated that mostly EFL undergraduate students had positive experiences and felt convenient in operating 4 out of 10 popular online learning applications. They preferred using WhatsApp Group, Email, Google Classroom, and YouTube channel during online learning. The recommendation is that lecturers use the most favourable online learning applications and design online engaging courses so that all undergraduate students keep feeling positive, enjoyable, and motivated to take online learning during the Covid-19 outbreak.
\end{abstract}

Keywords: EFL, Online Learning, Covid-19

$\begin{array}{lll}\text { History: } & & \text { Publisher: Undiksha Press } \\ \text { Received } & : \text { 4 January } 2021 & \text { Licensed: This work is licensed under } \\ \text { Revised } & : \text { 3 February } 2021 & \text { a Creative Commons Attribution 3.0 License } \\ \text { Accepted } & : \text { :26 March } 2021 & \text { CC () () } \\ \text { Published } & : \text { 25 April } 2021\end{array}$

\section{Introduction}

Coronavirus disease 19 or COVID-19 caused 2020 to become the most tragic year for humankind worldwide. First, it is caused by severe acute respiratory syndrome Coronavirus 2 (SARS-CoV-2); then, it becomes a highly contagious and transferable disease (Shereen et al., 2020). The first case of Coronavirus in Indonesia was reported on $2^{\text {nd }}$ March 2020 when a dance instructor and her mother got infected by their Japanese guest. From that moment on, the number of cases rose significantly and urged President Joko Widodo to instruct all citizens to work from home, study from home, and pray from home. The global spread of the COVID-19 has changed all human activities, including the learning process (Basilaia \& Kvavadze, 2020; Simamora, 2020), and it causes class suspension leading to the requirements of online learning (Moorhouse, 2020). As a result, the Minister of Education and Culture decided that teaching and learning processes and activities were implemented through elearning to reduce the spread of the COVID-19 outbreak and maintain the health of students, teachers, and educational staff (Atmojo \& Nugroho, 2020; Nartiningrum \& Nugroho, 2020).

During the COVID-19 outbreak, some researchers conducted similar research related to online learning applications at a certain level of education. For example, Sujarwo et al. (2020) investigated university students' perspective on utilising online learning during the COVID-19 pandemic. The respondents were 40 students of Elementary School Teacher 
Education, Physical Education, Sociology Education, and English Education Department of Universitas Megarezky in the 2019/2020 academic year. The results showed that they were interested in operating online learning, for it was accessible. Therefore, their perspective on online learning had a positive impact during the pandemic. Furthermore, it was similar to the research done by Sugianto \& Prasetyo. It showed that students' engagement in online learning during the pandemic was good (Sugianto \& Prasetyo, 2020).

On the other side, Nugroho (2020) focused on finding out students' perception in facing e-learning during COVID-19. The respondents were 126 students with different majors from 21 universities in Indonesia. The results showed that e-learning was quite helpful even though most students faced problems such as internet credit and signal and lack of technological knowledge. He concluded that the e-learning system was less successful in replacing the learning process in the classroom. Furthermore, similar research by Muslimin \& Harintama (2020) showed that students faced some challenges during the online course: poor internet connection (50\%), simultaneous agendas (30\%), limited WhatsApp features (10\%), and anxiety (10\%). To overcome those challenges, students did alternatives such as preparing the phone credit (30\%), praying for the end of the pandemic $(10 \%)$, learning extensively (10\%), searching the best spot to get a stable signal (20\%), setting the alarm (10\%), creating on-going motivation (20\%). It indicates that online learning offers impact on education, specifically students' growth (Cao et al., 2020). Furthermore, most teachers face challenges in the planning, implementation, and evaluation, and students encounter technological challenges during the COVID-19 pandemic (Atmojo \& Nugroho, 2020; Islam et al., 2015; Jhon et al., 2020).

Some previous studies reported the Indonesian students' perception of the effectiveness and also incompetency of some online learning platforms. One of them revealed that Indonesian students' top four e-learning platforms were Google Classroom, WhatsApp, Zoom, and Edmodo (Agung et al., 2020). The study also found that WhatsApp was the friendliest application among those four online learning platforms because it is not hard to install using low-end mobile phones. This application also worked on an unstable signal, and it helps students with low finance (Allo, 2020; Azhar, 2021). Furthermore, WhatsApp is a most loved online application for instructing and learning since students can utilise this application.

Moreover, WhatsApp furnishes various highlights with online media applications. Besides, Google Classroom reduces the necessity to print documents and risk losing them (Iftakhar, 2016). However, many students have problems accessing Zoom and Edmodo because they need proper gadgets to be installed and require more internet data to connect (Agung et al., 2020). On the other hand, Amin \& Sundari (2020) argued that free videoconferencing applications such as Zoom and Google Meet were proved to become answers for the absence of direct connections between teachers and students during online learning.

Another online learning application is Kahoot. Licorish et al. (2018) reported Kahoot as an ice breaker in the classroom truly helped the students learn in a fun way and motivated them to learn more, while Mada \& Anharudin (2019) found that Kahoot is not compatible with mediocre cellphones. This platform also does not work well on an unstable internet connection. Therefore, the right choice of the online learning platform or applications will significantly affect students' comfort in online learning.

Based on those circumstances, the assumption is that EFL undergraduate students have a positive perception even though they have to face some challenges in taking online learning during the pandemic. Therefore, this study is limited to EFL undergraduate students' perceptions (experience and comfort) in operating online learning applications. Having experience with online learning applications is the first time for undergraduate students during the pandemic. Besides, comfort deals with preferences and convenience in utilising 
educational technology. Therefore, the research objectives are to know EFL undergraduate students' perceptions and investigate online learning applications preferred by undergraduate students during the COVID-19 outbreak.

\section{Materials and Methods}

This study used qualitative descriptive research. Qualitative research can be a helpful way to understand a case predominantly and not only look at the causality but instead try to comprehend it (Akmal et al., 2020). The research took place at Universitas Indraprastha PGRI, Jakarta. A questionnaire with a Likert scale of four items was the research instrument prepared and intended to know the students' perceptions of online learning applications based on two indicators: experience and comfort. Before administering the research instrument to the respondents, researchers tried out the validity and reliability. The validity test used Pearson Product Moment ( $\geq 3.0$ ) (Sugiyono, 2011); then, 36 out of 40 items were valid. The reliability test used Cronbach's Alpha formula ( $\geq 0.70$ ) (Arikunto, 2010); then, the result was reliable (0.93).

This research used simple random sampling. The researcher provides the same opportunity for each member of the chosen population to be the samples carried out randomly without paying attention to the existing strata. The researchers then randomly chose two out of ten classes each semester. Therefore, 200 EFL undergraduate students were selected as samples from the regular class academic year 2019/2020 in the English Education Program.

The research procedure was that the questionnaire consisted of thirty-six valid and reliable closed-ended questions and one open-ended question. Then it was delivered to the 200 respondents by using Google form. The data collection took about a week. Next, the researchers analysed the obtained data qualitatively using a percentage to investigate EFL undergraduate students' perceptions of online learning applications during the COVID-19 outbreak

\section{Results and Discussion}

In this section, two indicators, namely, experience and comfort of online learning applications, are results. The category of percentage is divided into four: less than $40 \%$ is named poor or strongly negative, $40 \%-55 \%$ is named bad or negative, $56 \%-75 \%$ is named average or positive, and $76 \%-100 \%$ is named good or strongly positive. Some tables provide the results, followed by the interpretation of data. Tables 1-4 and figures 1-2 are the students' experience using online learning applications.

Table 1. The result of students' perception of the number of online course applications used by lecturer

\begin{tabular}{|c|c|c|c|c|c|c|}
\hline \multirow{2}{*}{ Observed Items } & \multicolumn{4}{|c|}{ Students' Responses } & \multirow{2}{*}{$\begin{array}{c}\text { Average } \\
\text { Percentage }\end{array}$} & \multirow{2}{*}{ Category } \\
\hline & 2 & 3 & 4 & $\geq 4$ & & \\
\hline $\begin{array}{l}\text { Number of online } \\
\text { learning applications } \\
\text { used by lecturers }\end{array}$ & 17.5 & 15.5 & 29.0 & 38.0 & 53.13 & Negative \\
\hline
\end{tabular}

Table 1 showed that $38 \%$ of EFL undergraduate students stated that most lecturers used more than four $(\geq 4)$ online learning applications during distance learning. It was contrary to the fact that the Head of the English Education Program had instructed all lecturers to provide one or two familiar and economical online learning applications. As a result, a perceptual mismatch between the Head's instruction and lecturers' decision on the 
numbers of online learning applications made EFL undergraduate students' perception negative.

Table 2. The result of students' perception of the number of online learning applications known by them

\begin{tabular}{|c|c|c|c|c|c|c|}
\hline \multirow{2}{*}{ Observed Items } & \multicolumn{4}{|c|}{ Students' Responses } & \multirow{2}{*}{$\begin{array}{l}\text { Average } \\
\text { Percentage }\end{array}$} & \multirow{2}{*}{ Category } \\
\hline & $\geq 4$ & 4 & 3 & 2 & & \\
\hline $\begin{array}{l}\text { The number of online learning } \\
\text { applications known by } \\
\text { undergraduate students }\end{array}$ & 45.0 & 19.0 & 24.0 & 12.0 & 74.25 & Positive \\
\hline
\end{tabular}

Table 2 showed that $45 \%$ of EFL undergraduate students said they had known more than four $(\geq 4)$ online learning applications during online distance learning, whereas $12 \%$ stated that they just knew two online learning applications. This finding has confirmed that some undergraduate students have quite good technological knowledge even though few of them were still unfamiliar with the latest online learning applications.

Table 3. The result of students' perception of the number of online learning applications mastered by them

\begin{tabular}{|c|c|c|c|c|c|c|}
\hline \multirow[t]{2}{*}{ Observed Items } & \multicolumn{4}{|c|}{ Students' Responses } & \multirow{2}{*}{$\begin{array}{c}\text { Average } \\
\text { Percentage }\end{array}$} & \multirow[t]{2}{*}{ Category } \\
\hline & $\geq 3$ & 3 & 2 & 1 & & \\
\hline $\begin{array}{l}\text { Types of online learning } \\
\text { applications mastered by } \\
\text { undergraduate students }\end{array}$ & 38.5 & 32.5 & 22.5 & 6.5 & 75.75 & Positive \\
\hline
\end{tabular}

Table 3 showed that $38.5 \%$ of EFL undergraduate students had mastered more than three $(\geq 3)$ online learning applications; $32.5 \%$ of students excelled in three (3) online learning applications, and $22.5 \%$ of them excelled in two (2) online learning applications. On the other hand, just $6.5 \%$ of students excelled in one online learning application. It happened because each lecturer applied different numbers of online learning applications in the online class. In addition, it made students familiar with and able to operate some online learning applications used by their lecturers. As a result, their technological learning mastery is quite good.

Table 4. The result of students' perception of the effectiveness of online learning applications

\begin{tabular}{|c|c|c|c|c|c|c|}
\hline \multirow{2}{*}{ Observed Items } & \multicolumn{4}{|c|}{ Students' Responses } & \multirow{2}{*}{$\begin{array}{c}\text { Average } \\
\text { Percentage }\end{array}$} & \multirow[t]{2}{*}{ Category } \\
\hline & $\begin{array}{l}\text { highly } \\
\text { effective }\end{array}$ & effective & ineffective & $\begin{array}{c}\text { highly } \\
\text { ineffective }\end{array}$ & & \\
\hline $\begin{array}{l}\text { The effectiveness of } \\
\text { online learning } \\
\text { applications during } \\
\text { distance learning }\end{array}$ & 4.0 & 45.0 & 44.5 & 6.5 & 61.63 & Positive \\
\hline
\end{tabular}

Table 4 showed that $45 \%$ of students stated that the use of online learning applications was effective. There is no much different percentage between effective and ineffective 
students' responses. Fortunately, the online class could run even though there were some problems during distance learning.

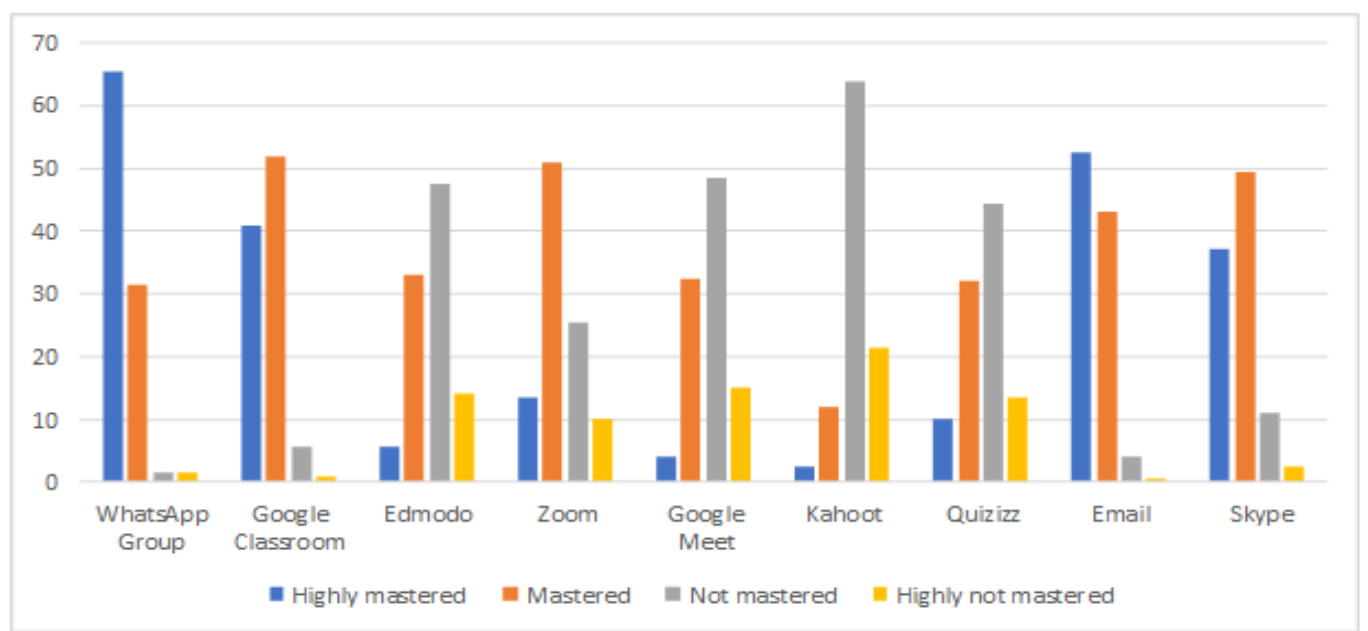

Figure 1. The result of students' perception of the ability in operating online learning applications

Figure 1 is about students' ability in the use of online learning applications. It showed that $65.5 \%$ of undergraduate students highly mastered WhatsApp Group. In addition, $52 \%$ of undergraduate students mastered Google Classroom. On the other hand, $64 \%$ of undergraduate students did not master Kahoot, and $21.5 \%$ of them did not highly master Kahoot either. The most and least mastered online learning applications sequence was WhatsApp Group followed by Email, Google Classroom, YouTube Channel, Zoom, Skype, Quizizz, Edmodo, Google Meet, and the least one was Kahoot.

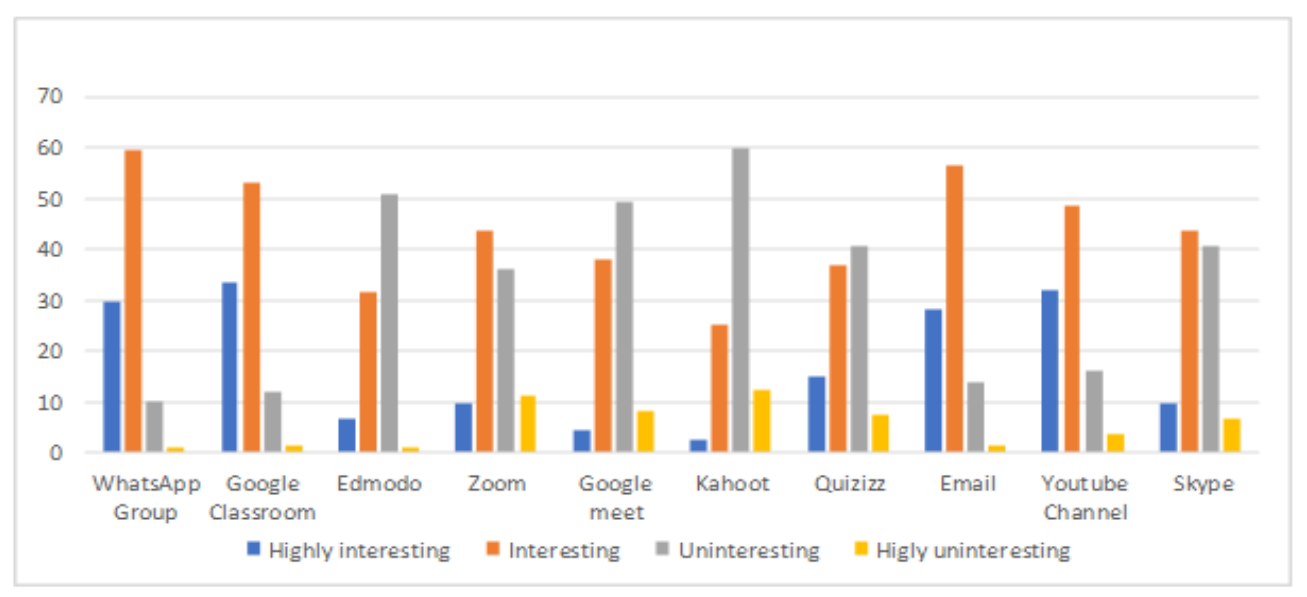

Figure 2. The result of students' perception of the interest in online learning applications

Figure 2 showed that $33.5 \%$ of undergraduate students were highly interested in using Google Classroom. 59.5\% of them were interested in WhatsApp Group. On the other hand, $60 \%$ of undergraduate students were uninterested in using Kahoot. Moreover, $12 \%$ of them were highly uninterested in Kahoot either. In short, the sequence of the most and least interesting online learning applications was Google Classroom followed by WhatsApp Group, Email, YouTube Channel, Quizizz, Skype, Zoom, Google meet, Edmodo, and the least one was Kahoot. The next indicator is the students' comfort. Figure 3 and Table 5 are the results of students' comfort with online learning applications. 


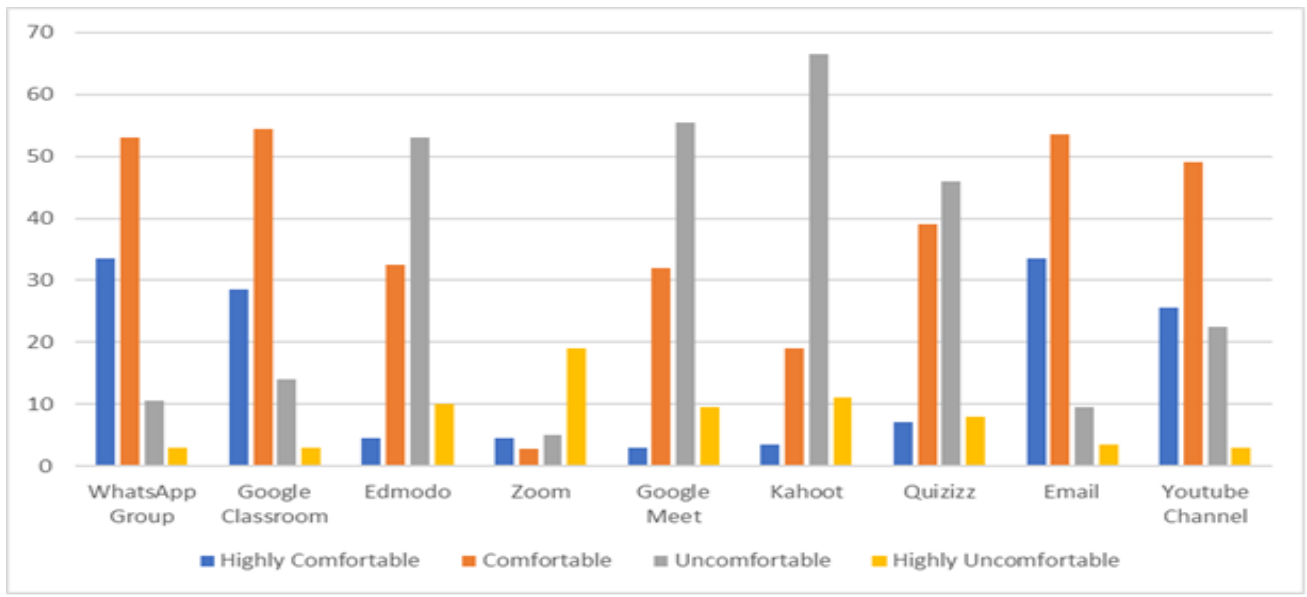

Figure 3. The result of students' perception of the comfort of online learning applications

The diagram above illustrates that $33.5 \%$ of students were highly comfortable with WhatsApp Group and Email. Furthermore, $54.5 \%$ of them were comfortable with Google Classroom. On the other hand, 66.5\% were uncomfortable with Kahoot, and 19\% were highly uncomfortable with Zoom. Thus, the most and least comfortable online learning applications sequence was WhatsApp Group, followed by Email, Google Classroom, YouTube Channel, Quizizz, Skype, Edmodo, Google Meet, Zoom, and the least one was Kahoot.

Table 5. The result of students' perception of technological devices

\begin{tabular}{|c|c|c|c|c|c|c|}
\hline \multirow[b]{2}{*}{ Observed Items } & \multicolumn{4}{|c|}{ Students' Responses } & \multirow[b]{2}{*}{$\begin{array}{c}\text { Average } \\
\text { Percentage }\end{array}$} & \multirow[b]{2}{*}{ Category } \\
\hline & $\begin{array}{l}\text { highly } \\
\text { effective }\end{array}$ & $\begin{array}{c}\text { effecti } \\
\text { ve }\end{array}$ & $\begin{array}{l}\text { ineffe } \\
\text { ctive }\end{array}$ & $\begin{array}{c}\text { highly } \\
\text { ineffective }\end{array}$ & & \\
\hline $\begin{array}{l}\text { 1. Undergraduate } \\
\text { students' opinions about } \\
\text { using a handphone } \\
\text { during online learning }\end{array}$ & 5.0 & 45.5 & 39.0 & 10.5 & 61.25 & Positive \\
\hline $\begin{array}{l}\text { 2. Undergradute } \\
\text { students' opinions about } \\
\text { using a laptop/netbook } \\
\text { during online learning }\end{array}$ & 10.0 & 45.0 & 36.0 & 9.0 & 64.0 & Positive \\
\hline
\end{tabular}

Furthermore, table 5 is concerned with students' perception of technological devices. $45.5 \%$ of students felt comfortable using a handphone, and $45 \%$ of them also felt convenient with a laptop/netbook during distance learning.

Table 6. The average percentage of indicators of undergraduate students' perceptions of online learning applications

\begin{tabular}{lcc}
\hline $\begin{array}{c}\text { Indicators of undergraduate students' } \\
\text { perceptions of online learning applications }\end{array}$ & $\begin{array}{c}\text { Average } \\
\text { Percentage }\end{array}$ & Category \\
\hline $\begin{array}{l}\text { 1. Undergraduate students' experience of } \\
\text { online learning applications }\end{array}$ & $68.24 \%$ & Average/Positive \\
$\begin{array}{l}\text { 2. Undergraduate students' comfort of online } \\
\text { learning applications comfort }\end{array}$ & $64.95 \%$ & Average/Positive \\
\hline
\end{tabular}


As shown in Table 6, the average total percentage of students' perception of online learning applications experience was slightly higher than the average percentage of students' perception of online learning applications comfort, but both have a similar positive category. Thus, it seemed that EFL undergraduate students had a positive experience and felt convenient using online learning applications during the COVID-19 outbreak.

\section{Discussion}

The research results prove that each indicator has similar percentages $(68.24 \%$ and $64.95 \%$ ) and the same categories (average/positive). The first indicator is the students' perception of the online learning applications experience. The interpreted data revealed that lecturers provided more than four online applications. It was contrary to the fact that the Head of the English Education Program had instructed all lecturers to provide one or two familiar and economical online learning applications since most students complained about the internet's problems such as the excess of quota and unstable internet access (Nartiningrum \& Nugroho, 2020). Besides, a few of them were unfamiliar to operate online learning applications at the beginning of online learning. This result is consistent with Lister (2014), who stated that one of the barriers in online learning is technology and internet facilities among educators and students. This is a challenge because good lecturers have more excellent skills and know-how on information technology and can use more advanced technology architectures. In contrast, students have a lack of knowledge of basic information technology architectures. Surprisingly, in the next few online learning meetings, $45 \%$ of students had known more than four online applications, and $38.5 \%$ of students were able to operate more than three online applications.

Based on research findings, it is suggested that lecturers apply two or three online learning applications that are favourable, economical, and mastered by all undergraduate students in the following semester. Besides, lecturers' and students' skills to use online platforms, adequate internet facilities, and online guidelines are also prerequisites to implement online learning smoothly. Dealing with ten popular online learning applications, the most and least mastered online applications were WhatsApp Group, followed by Email, Google Classroom, YouTube Channel, Zoom, Skype, Quizizz, Edmodo, and Google Meet, and Kahoot. Since there was no in depth-interview, the researchers employed an open-ended question to support the data. Students gave some opinions about online learning applications during studying at home. They said that the WhatsApp group was the most favourable and effective online learning application. It was easy, economical, and accessible. The features also supported their learning. They understood courses such as Phonology, Pronunciation, and Speaking through Voice Note and Video Call. Research by Barhoumi (2015) determined that WhatsApp was a friendly application, and students were already familiar with it. They could send assignments in the form of text, video, audio, file, or photo easily within two-way interaction. Besides, the most and least interesting online learning applications were Google Classroom followed by WhatsApp Group, Email, YouTube Channel, Quizizz, Skype, Zoom, Google meet, Edmodo, and Kahoot. Dealing with students' perception of Google Classroom, Sibuea (2018) confirmed that this application is a satisfying online learning platform since Google Classroom can be installed on mobile; therefore, users can use it anytime and anywhere. It also integrates with other Google products: Google Docs, Google Drive, YouTube, Google Form, and Google Calendar in one place. Lecturers and EFL students from the Faculty of Economics and Business at Universitas Bhayangkara also agreed that Google Classroom was exciting and effective in implementing online learning during the pandemic (Puspitorini, 2020).

The second indicator is the students' perception of the comfort of the use of online learning applications. The most and least comfortable online learning applications was 
WhatsApp Group followed by Email, Google Classroom, YouTube Channel, Quizizz, Skype, Edmodo, Google Meet, Zoom, and Kahoot. According to Agung et al. (2020), WhatsApp was the most compatible online learning platform because it can be easily installed using low-end mobile phones and worked well on an unstable signal. Undergraduates' perception was strongly positive of three online learning applications: WhatsApp Group, Email, and Google Classroom. Their perception was positive of five online learning applications: YouTube Channel, Quizizz, Skype, Edmodo, and Google Meet. On the other side, their perception was negative of two online learning applications: Zoom and Kahoot. Students were enthusiastic about operating Zoom Meeting at the beginning of online learning based on students' opinions. They could see and talk to their lecturer and beloved classmates virtually. Unfortunately, the connection was sometimes unstable, and it consumed a lot of internet quota. This contrasts with a study done by (Nartiningrum \& Nugroho, 2020), who mentioned the students' suggestion to use Zoom and Google Meet as a solution for the absence of student-teachers interaction. Besides, Kahoot was unfamiliar to both lecturers and students. Talking about technological devices during distance learning, students were comfortable using either a handphone or a laptop/netbook during distance learning.

It can be concluded that there are some similarities between the two indicators. Firstly, they have similar percentages $(68.24 \%$ and $64.95 \%)$ and the same categories (average/positive). Secondly, there are four most and a least mastered, engaging, and comfortable online learning applications preferred by undergraduate students. The most mastered, engaging, and comfortable online learning applications were WhatsApp Group, Email, Google Classroom, and YouTube Channel. On the other side, the least one was Kahoot. It is similar to Mada \& Anharudin (2019) study, which showed that Kahoot was considered a complex platform because it is challenging to be installed from unsophisticated handphones, and it requires extra internet data to access. This platform also does not work well on an unstable internet connection.

Eventually, this study has a few strengths and limitations. To the best of our knowledge, this is the first study regarding students' perceptions on the use of online learning applications which highlighted the two indicators (experience and comfort) and administered in the COVID-19 pandemic, while other similar research with the same indicators was done under normal circumstances (Astani et al., 2010; Barbour \& Adelstein, 2013; Holzweiss et al., 2014; Rodriguez et al., 2018). A further strength of our study is that the research was carried out for the first time in the English Education Program, Universitas Indraprasta PGRI. However, the first limitation of this study was the instrument. The researchers used an online questionnaire with closed-ended questions and an open-ended question without an online interview. As a result, the discussion was not elaborated deeply. Besides, the sample was taken from the regular class only. In the future, other researchers will need to conduct similar research with an interview and take various samples so that the obtained data can be extended and generalised to all programs or faculties at Universitas Indraprasta PGRI.

\section{Conclusion}

Based on results and discussion, most EFL undergraduate students had positive perceptions of online learning applications during the COVID-19. They had good experiences and felt convenient in operating four out of ten popular online learning applications. They considered using WhatsApp Group, Email, Google Classroom, and YouTube channel. The four online learning applications are user-friendly, economical, and helpful. Therefore, lecturers should keep on using and maintaining the most popular and favourable online learning applications during distance learning so that all students feel enjoyable and motivated, and they can keep having positive perceptions of taking online learning. 


\section{References}

Agung, A. S. N., Surtikanti, M. W., \& Quinones, C. A. (2020). Students' Perception of Online Learning during COVID-19 Pandemic: A Case Study on the English Students of STKIP Pamane Talino. Soshum: Jurnal Sosial Dan Humaniora, 10(2), 225-235. https://doi.org/10.31940/soshum.v10i2.1316

Akmal, S., Dhivah, I., \& Mulia, M. (2020). Investigating students' interest on reading journal articles: Materials, reasons and strategies. Studies in English Language and Education, 7(1), 194-208. https://doi.org/10.24815/siele.v7i1.15358

Allo, M. D. (2020). Is the online learning good in the midst of Covid-19 Pandemic? The case of EFL learners. Jurnal Sinestesia, 10(1), 1-10. https://sinestesia.pustaka.my.id/journal/article/view/24

Amin, F. M., \& Sundari, H. (2020). EFL students' preferences on digital platforms during emergency remote teaching: Video conference, lms, or messenger application? Studies in English Language and Education, 7(2), 362-378. https://doi.org/10.24815/siele.v7i2.16929

Arikunto, S. (2010). Prosedur Penelitian Suatu Pendekatan Praktik. Rineka Cipta.

Astani, M., Ready, K. J., \& Duplaga, E. A. (2010). Online course experience matters: Investigating students' perceptions of online learning. Issues in Information Systems, 11(2), 14-21. https://doi.org/10.48009/2_iis_2010_14-21.

Atmojo, A. E. P., \& Nugroho, A. (2020). EFL Classes Must Go Online! Teaching Activities and Challenges during COVID-19 Pandemic in Indonesia. Register Journal, 13(1), 49-76. https://doi.org/10.18326/rgt.v13i1.49-76.

Azhar, A. (2021). Online Learning amid the COVID-19 Pandemic: A Case Study of the State Islamic University of Mataram. Nadwa, 14(2), 265-276. https://doi.org/10.21580/nw.2020.14.2.6639.

Barbour, M. K., \& Adelstein, D. (2013). High-school students' perceptions of effective online course design. The Morning Watch, 41(1-2), 56-65. https://doi.org/10.19173/irrodl.v18i3.2800.

Barhoumi, C. (2015). The Effectiveness Of WhatsApp Mobile Learning Activities Guided by Activity Theory on Students' Knowldege Management. Contemporary Educational Technology, 6(3), 221-238. https://eric.ed.gov/?id=EJ1105764.

Basilaia, G., \& Kvavadze, D. (2020). Transition to Online Education in Schools during a SARS-CoV-2 Coronavirus (COVID-19) Pandemic in Georgia. Pedagogical Research, 5(4). https://doi.org/10.29333/pr/7937.

Cao, W., Fang, Z., Hou, G., Han, M., Xu, X., Dong, J., \& Zheng, J. (2020). The psychological impact of the COVID-19 epidemic on college students in China. Psychiatry Research, 287. https://doi.org/10.1016/j.psychres.2020.112934.

Holzweiss, P. C., Joyner, S. A., Fuller, M. B., Henderson, S., \& Young, R. (2014). Online graduate students' perceptions of best learning experiences. Distance Education, 35(3), 311-323. https://doi.org/10.1080/01587919.2015.955262.

Iftakhar, S. (2016). Google classroom: what works and how? Journal of Education and Social Sciences, 3(2), 12-18. http://jesoc.com/wpcontent/uploads/2016/03/KC3_35.pdf.

Islam, N., Beer, M., \& Slack, F. (2015). E-Learning Challenges Faced by Academics in Higher Education: A Literature Review. Journal of Education and Training Studies, 3(5), 102-112. https://doi.org/10.11114/jets.v3i5.947.

Jhon, W., Mustadi, A., \& Zubaidah, E. (2020). Online Learning during Covid-19 Pandemic in Developing Countries : Does it run well ? Jurnal Pendidikan Progresif, 10(3), 440- 
454. https://doi.org/10.23960/jpp.v10.i3.202006.

Licorish, S. A., Owen, H. E., Daniel, B., \& George, J. L. (2018). Students' perception of Kahoot!'s influence on teaching and learning. Research and Practice in Technology Enhanced Learning, 13(1), 1-23. https://doi.org/10.1186/s41039-018-0078-8.

Lister, M. (2014). Trends in the Design of E-Learning and Online Learning. MERLOT Journal of Online Learning and Teaching, 10(4), 671-680. https://search.proquest.com/openview/c58ac1d7c94c639ea7cba6605b51bff4/1?pqorigsite $=$ gscholar \&cbl $=2030650$.

Mada, R. D., \& Anharudin, A. (2019). How Online Learning Evaluation (Kahoot) Affecting Students' Achievement and Motivation (Case Study on it Students). International Journal for Educational and Vocational Studies, 1(5), 422-427. https://doi.org/10.29103/ijevs.v1i5.1494.

Moorhouse, B. L. (2020). Adaptations to a face-to-face initial teacher education course 'forced'online due to the COVID-19 pandemic. Journal of Education for Teaching, 46(4), 609-611. https://doi.org/10.1080/02607476.2020.1755205.

Muslimin, A. I., \& Harintama, F. (2020). Online Learning during Pandemic: Students' Motivation, Challenges, and Alternatives. Loquen: English Studies Journal, 13(2), 60. https://doi.org/10.32678/loquen.v13i2.3558.

Nartiningrum, N., \& Nugroho, A. (2020). Online Learning amidst Global Pandemic: EFL Students' Challenges, Suggestions, and Needed Materials. ENGLISH FRANCA: Academic Journal of English Language and Education, 4(2), 115-140. https://doi.org/10.29240/ef.v4i2.1494.

Nugroho, A. D. (2020). How E-Learning Deals with Higher Education during the Pandemic in Indonesia. Loquen: English Studies Journal, 13(2), 51. https://doi.org/10.32678/loquen.v13i2.3555.

Puspitorini, F. (2020). Strategi Pembelajaran Di Perguruan Tinggi Pada Masa Pandemi Covid-19. Jurnal Kajian Ilmiah, 1(1), 99-106. https://doi.org/10.31599/jki.v1i1.274.

Rodriguez, M. C., OOms, A., \& Montanez., M. (2018). Students' Perception of Online Learning Quality given Comfort, Motivation, Satisfaction, and Experience. Journal of Interactive Online Learning, $\quad 7(2), \quad 105-125$. https://www.ncolr.org/jiol/issues/pdf/7.2.2.pdf.

Shereen, M. A., Khan, S., Kazmi, A., Bashir, N., \& Siddique, R. (2020). COVID-19 infection: Origin, transmission, and characteristics of human coronaviruses. Journal of Advanced Research, 1(1), 73-80. https://doi.org/10.31599/jki.v1i1.265.

Sibuea, T. F. B. (2018). Students' perception on the use of Google Classroom to support blended learning for the Pengantar Linguistik Umum course. LINGUA, Jurnal Ilmiah Bahasa Dan Budaya, 14(2), 1-14. https://doi.org/10.35962/lingua.v14i2.45.

Simamora, R. M. (2020). The Challenges of Online Learning during the COVID-19 Pandemic: An Essay Analysis of Performing Arts Education Students. Studies in Learning and Teaching, 1(2), 86-103. https://doi.org/10.46627/silet.v1i2.38.

Sugianto, A., \& Prasetyo, I. A. (2020). Unravelling the Lecturer's feedback quality and the Students' engagement in Online Learning. Loquen: English Studies Journal, 13(2), 69. https://doi.org/10.32678/loquen.v13i2.3588.

Sugiyono. (2011). Metode Penelitian Kuantitatif, Kualitatif, dan R\&D. Alfabeta.

Sujarwo, S., Sukmawati, S., Akhiruddin, A., Ridwan, R., \& Siradjuddin, S. (2020). An Analysis of University Students' Perspective On Online Learning in The Midst of Covid-19 Pandemic. Jurnal Pendidikan Dan Pengajaran, 53(2), 125. https://doi.org/10.23887/jpp.v53i2.24964. 